\title{
Opportunities to Enhance the Pyrolysis of Biomass in The Production of Hydroxyapatite and Chemicals
}

\author{
Juan Proano-Aviles* \\ Department of Mechanical Engineering, Universidad San Francisco de Quito, Ecuador
}

*Corresponding author: Juan Proano-Aviles, Mechanical Engineering, Universidad San Francisco de Quito, Diego de Robles S/N y Pampite, Quito, Pichincha, Ecuador, Email: jsproano@usfq.edu.ec

To Cite This Article: Juan Proano-Aviles. Opportunities to Enhance the Pyrolysis of Biomass in The Production of Hydroxyapatite and Chemicals. 2020 - 8(5). AJBSR.MS.ID.001315. DOI: 10.34297/AJBSR.2020.08.001315.

Received: 制 April 15, 2020; Published: 眥 May 01, 2020

\begin{abstract}
The pyrolysis of calcium orthophosphates produces hydroxyapatite and chemicals. Additionally, pyrolysis proposes paths to manage animalderived waste streams. As it happens in the pyrolysis of lignocellulosic biomass, operating variables like reactor temperature, reaction atmosphere, feedstock, and particle size affect the final product from animal-biomass. This review summarizes the characteristics of multiple pyrolysis methods to produce hydroxyapatite and chemicals. Finally, this short paper recommends opportunities to enhance the results by changing pyrolysis process variables, learning from lignocellulosic and animal-derived biomass experiences alike.
\end{abstract}

Keywords: Hydroxyapatite; Calcium Orthophosphates; Biomass; Pyrolysis; Combustion, Thermochemical Conversion; Bone meal; Ceramic Powder

Abbreviations: HAP: Hydroxy Apatite; COP: Calcium Ortho Phosphates; LCB: Ligno Cellulosic Biomass; COPB: Calcium Ortho PhosphateContaining Biomass; TCB: Thermochemical Processing of Biomass; MBM: Meat and Bone Meal

\section{Introduction}

Calcium orthophosphates (COP) are the main inorganic constituent of hard tissue found in animals like bone, dental pieces, antlers, tendons, eggshells, seashells, and corals [1-5]. Moreover, $\mathrm{COP}$ is the precursor for synthesizing hydroxyapatite (HAp). There are multiple applications for HAp, including tissue engineering, bioactive and non-bioactive coatings, filtering media, heat generation, and production of upgradeable chemicals [2,3,6-11]. A plethora of methodologies is available in the literature to obtain HAp, which includes the use of chemical, mechanical, and thermal processes [12]. The raw material, biomass, to produce HAp can be bone specimens, bone particles or powder, or bone meal from the seafood, bovine, swine, poultry, and sheep food processing industry. COP usage and HAp applications involve multiple disciplines like medicine, dentistry, engineering, environmental remediation, and waste management.

Thermochemical processing of biomass is one route used to produce HAp. However, the literature on this topic predominantly covers lignocellulosic biomass (LCB) processing. These processes presented parallel development when using calcium orthophosphates (COPB) as the feedstock. In LCB processing, multiple projects have studied the effect of variables like reaction temperature, atmosphere reactiveness, catalyst usage, pressure, and solvents to increase the yield and properties of the products [13-15]. Moreover, the heating rates influence the distribution of products from processing LCB. For example, during the pyrolysis of LCB, slow heating rates favor the production of a solid charcoal-like product, meanwhile higher heating rates promote the production of room temperature condensable products, known as bio-oil. Moreover, heating rates are dependent mainly on particle size, reactor temperature, heat transfer mechanisms, and initial biomass properties [16-19].

Combustion and pyrolysis are among the literature reported thermal processes to obtain HAp [12,20-26]. Likewise, these methods can produce bone char, the solid product from bone processing, as well as liquid and gaseous products that can recover upgradeable organic materials for obtaining chemicals, pharmaceuticals, or energy carriers $[27,28]$. This review covers the basics of the thermochemical processing of biomass, and it compiles pyrolysis variables and trends to find opportunities for 
improving yields and product distribution when processing COPB into HAp and other value-added products.

\section{Lignocellulosic Biomass Pyrolysis}

Pyrolysis is the thermal decomposition of organic matter in the presence of an oxygen-poor or deprived atmosphere [29]. LCB pyrolysis yields room-temperature non-condensable gases, solid charcoal, and liquid bio-oil [30]. The latter is an attractive source of organic matter and has a variety of carbohydrate-derived compounds that are upgradable into fuels and chemicals. Multiple studies report that increasing heating rates, decreasing initial biomass particle size, and using proper reactor temperatures lead to higher bio-oil yields [31-34]. Fast pyrolysis of LCB uses reactor temperatures close to $500^{\circ} \mathrm{C}$, particle residence times shorter than $2 \mathrm{~s}$, and heating rates larger than $10^{\circ} \mathrm{C} / \mathrm{s}[35,36]$. With high furnace temperatures, these heating rates are attainable when particles are in the millimeter-scale or smaller [37,38]. Also, stage fractionation of the bio-oil allows separating compounds, which helps their extraction or further upgrading [14,39]. Alternatively, these variables influence the properties of the solid product, promoting the release of volatile compounds from the biomass, leaving pores, and maintaining some of the initial structure [40].

These pyrolysis reactions are complex, and heat/mass transfer affects the preference of competing pathways. During the pyrolysis of LCB, the release of levoglucosan decreases in mass-transferlimited cases. Since levoglucosan stays in the liquid phase, it thermally degrades instead of leaving as a volatile gas [31,41].

\section{Pyrolysis of COPB in The Literature}

Multiple examples of pyrolysis of COPB use different technologies, operating parameters, and feedstock to produce HAp and other chemicals. The feed stocks processed with pyrolysis are mainly meat and bone meal (MBM), raw food waste, eggshells, oyster shells, and COP solutions. The products from these pyrolysis experiments were bone char, HAp, and chemicals. Figure 1 summarizes these examples presenting reactor temperatures, reactor type, and reacting gas.

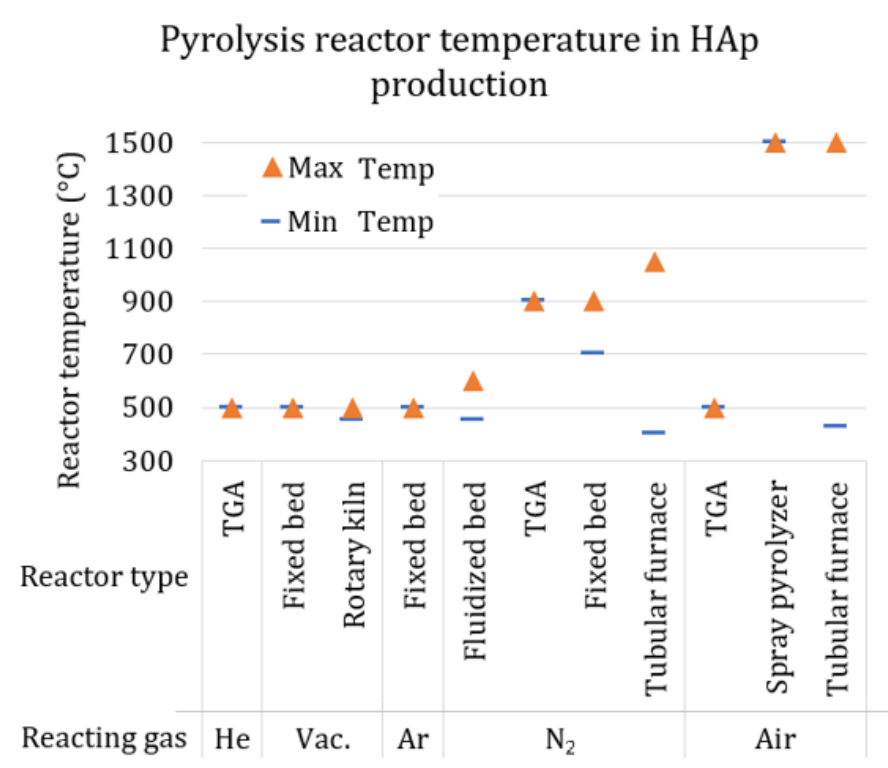

Figure 1: Summary of pyrolysis temperatures used in the production of HAp, organized by reactor type and reacting gas or vacuum (Vac.) $[8,9,22,27,42-58$,$] .$

Figure 1 shows a variety of reactors that are also common in LCB processing. Thermogravimetric analyzer (TGA) is a powerful tool to perform controlled pyrolysis of milligram-scale samples, with insight on mass loss time evolution; however, this instrument has low heating rates close to $3^{\circ} \mathrm{C} / \mathrm{s}\left(120^{\circ} \mathrm{C} / \mathrm{min}\right)[59,60]$. The furnace temperature ranges from 450 up to $150{ }^{\circ} \mathrm{C}$ in the projects reported. Not included in the summary, an arc plasma reactor reached temperatures close to $4200^{\circ} \mathrm{C}$ to treat oyster shells and food waste with disinfection and material recovery purposes [58]. Not all the projects reported heating rates. Even knowing reactor temperatures and particle size, the estimation of heating rates needs more input to be determined. However, reactors such as fluidized beds or preheated tubular furnaces with a high temperature and small feedstock particle size are useful to perform fast pyrolysis of LCB [61-63].

Regarding the reaction atmosphere, vacuum, argon, and nitrogen prevent oxidative reactions of the volatile compounds released during pyrolysis, allowing higher recovery of organic compounds in the bio-oil. Use of air as the carrier gas in some of the experiments with COPB usually promotes oxidation reactions when the organic volatiles are not the main goal of the process, but the production of clean bone char. 


\section{Products From COPB Pyrolysis and Their Relation- ship with Processing Variables}

The projects summarized in Figure 1 mainly produced HAp, but some of them investigated the liquid products and the bone char. As in LCB pyrolysis, the projects with reactors capable of higher heating rates produced and collected bio-oil. [27] used a fluidized bed reactor to produce liquid yields of up to $43 \mathrm{wt} . \%$ of initial MBM at $550{ }^{\circ} \mathrm{C}$. Since the biomass initially had fats and proteins, their bio-oil included fatty acids and fatty nitriles/amides. However, the most abundant were aliphatic compounds with functional groups involving either nitrogen or oxygen. [56], using a pilot-scale fluidized bed reactor, produced bio-oil that had the same main abundant products, but the maximum bio-oil yield was $30 \mathrm{wt} . \%$. They also found chlorine-containing compounds that make the liquid product difficult to use as a fuel. Starting from bone, [55] produced bio-oil as well, in a vertical retort with a relatively low heating rate and much less initial organic material. The liquid yield was less than $5 \mathrm{wt} . \%$ and they found organic acids and asphaltenes as predominant products. These publications show a detailed product distribution with varying concentrations that present other chemicals like phenolic compounds, acids, and aromatics with downstream potential for separation or upgrading.

Looking at the solid products side, [46] produced nanosized HAp powder with regular spherical morphology using flame spray pyrolysis. Moreover, the stoichiometry was right for enhanced properties of densification, osseointegration, and bioreactivity. Flame pyrolysis, in general, presents high heating rates and high reaction temperatures. [51] produced HAp by pyrolyzing an aerosol. The used reactor was a $500{ }^{\circ} \mathrm{C}$ tubular furnace, much cooler than in the flame pyrolysis case. The product of the process were hollow spherical micrometer-scale particles with homogeneous chemical composition, but uneven crystal morphologies.

Further thermal treatment at $1050^{\circ} \mathrm{C}$ allowed obtaining changes in crystallite size and morphology. [8] slowly pyrolyzed specimens of porcine and bovine bone to understand various physical, mechanical, and electrical properties of the resulting solid product as a bone substitute in medical applications. In general, the products obtained were highly porous and with mechanical properties like those of human bones. Additionally, products from $950^{\circ} \mathrm{C}$ furnace pyrolysis reached close to stoichiometric HAp, Ca/P ratios similar to 1.67. [64] evidenced the changes in the crystalline structure of bone char when increasing the furnace pyrolysis temperature. With low heating rates in this type of reactors, the duration of the process provoked changes in the structure of the char. They report that the chemical structure did not change by pyrolysis. Additionally, they did not find HAp degradation, an idea commonly supported in the literature, except by $[64,65]$.

\section{Opportunities with The Pyrolysis of COPB}

Optimization of pyrolysis process variables, mainly heating rates and furnace temperature, combined with a thorough grasp of feedstock properties, can open routes to increase quantity and quality of bio-oil from COPB. Moreover, using pyrolysis as a pretreatment of the HAp precursors, such as MBM, may lead to recovering organic chemicals from otherwise removed and rejected materials. Stage fractionation of bio-oil compounds obtained from COPB pyrolysis, especially the ones that carry fats and proteins, may improve the collection of value-added products, either directly or after upgrading steps. Understanding the effect of pyrolysis variables on stoichiometric composition, crystallinity, chemical structure, and morphology of HAp will allow tailoring the process to produce better materials for medical applications. Microgram-scale pyrolysis furnaces with high heating rates and short processing times will accelerate the study of pyrolysis conditions and products. Moreover, these reactors can input their gaseous product for compound identification and quantification into specialized analyzers.

Broadening the acceptable feedstock options and qualities for pyrolysis can expose pathways to manage wastes otherwise landfilled or poorly managed. Moreover, this may lead to adding value to the waste streams, consequently activating economic activity in the waste management sector. Techno-economic analysis of pathways to process biomass to obtain value-added products can reveal feasible projects that can promote their scalability and proliferation.

\section{References}

1. V Gshalev, et al. (Eds.). Hydroxyapatite: synthesis, properties, and applications.

2. I Smičiklas, J Papan, V Lazić, D Lončarević, SP Ahrenkiel, et al. (2017) Functionalized biogenic hydroxyapatite with 5-aminosalicylic acid Sorbent for efficient separation of $\mathrm{Pb} 2+$ and $\mathrm{Cu} 2+$ ions, J Environ Chem Eng 5(4): 3759-3765.

3. BR Sunil, M Jagannatham (2016) Producing hydroxyapatite from fish bones by heat treatment, Mater Lett 185: 411-414.

4. N Tangboriboon, J Suttiprapar (2016) Innovative Preparation Calcium Hydroxyapatite from Duck Eggshell via Pyrolysis. Appl Mech Mater 851: 8-13.

5. Y Oshida, (2015) Hydroxyapatite: Synthesis and Applications. Momentum Press, USA.

6. EM Nigri, A Bhatnagar, SDF Rocha (2017) Thermal regeneration process of bone char used in the fluoride removal from aqueous solution. J Clean Prod 142 (2017): 3558-3570.

7. Y Zhang, Z Ma, J Yan (2018) Influence of pork and bone on product characteristics during the fast pyrolysis of pig carcasses, Waste Management. 75: 352-360.

8. M Krzesińska, J Majewska (2015) Physical properties of continuous matrix of porous natural hydroxyapatite related to the pyrolysis temperature of animal bones precursors. J Anal Appl Pyrolysis. 116: 202-214 
9. G Skodras, P Grammelis, P Basinas (2007) P Basinas Pyrolysis and combustion behaviour of coal-MBM blends, Bioresour. Technol. 98 : 1-8.

10. M Kantorek, K Jesionek, S Polesek-Karczewska, P Ziółkowski, J Badur , et al. (2019) Thermal utilization of meat and bone meals. Performance analysis in terms of drying process, pyrolysis and kinetics of volatiles combustion. Fuel 254

11. M Ibrahim, M Labaki, J Giraudon, J Lamonier (2020) Hydroxyapatite a multifunctional material for air, water and soil pollution control : A review. Journal of Hazard Materials 383.

12. E Cascarosa, G Gea, J Arauzo (2012) Thermochemical processing of meat and bone meal: A review, Renew. Sustain Energy Rev 16: 942-957.

13. A V Bridgwater (2012) Review of fast pyrolysis of biomass and product upgrading. Biomass and Bioenergy 38: 68-94.

14. AS Pollard, MR Rover, RC Brown (2012) Characterization of biooil recovered as stage fractions with unique chemical and physical properties. J Anal Appl Pyrolysis 93: 129-138.

15. Lédé (2013) Biomass Fast Pyrolysis Reactors: A Review of a Few Scientific Challenges and of Related Recommended Research Topics. Oil Gas Sci Technol- Rev d IFP Energies Nouv 68: 801-814.

16. B Babu, A Chaurasia (2003) Modeling for pyrolysis of solid particle: kinetics and heat transfer effects, Energy Conversion and Management $44: 2251-2275$.

17. BV Babu, AS Chaurasia (2004) Pyrolysis of biomass: Improved models for simultaneous kinetics and transport of heat, mass and momentum Energy Conversion and Management. 45: 1297-1327.

18. J Proano-Aviles, JK Lindstrom, PA Johnston, RC Brown (2017) Heat and Mass Transfer Effects in a Furnace-Based Micropyrolyzer, Energy Technolology 5: 189-195.

19. L Brown, DC Dayton, MR Nimlos, JW Daily, P Adisak, et al. (2011) Characteristics of fast pyrolysis of biomass in a free fall reactor. Bioresour Technol 102: 863-871.

20. Y Yuan, C Liu, Y Zhang, X Shan (2008) Sol-gel auto-combustion synthesis of hydroxyapatite nanotubes array in porous alumina template. Materials Chemisrtry and Physics 112: 275-280.

21. M Ayllón, G Gea, MB Murillo, JL Sánchez, J Arauzo, et al. (2005) Kinetic study of meat and bone meal pyrolysis: an evaluation and comparison of different possible kinetic models. Journal of Analytical and Applied Pyrolysis 74: 445-453.

22. A Chaala, C Roy (2003) Recycling of meat and bone meal animal feed by vacuum pyrolysis. Environ Sci Technol 37(19): 4517-4522.

23. JB Fantinatti, JM Mesa-Perez, J D Rocha, RC Martins, RH Aguiar, et al. (2012) Fast pyrolysis agro waste of bone meal to obtain bio-oil and biochar Energy Biomass Biol Residues. International Conference of Agricultural Engineering (CIGR-AgEng) Agric Eng, Spain 8-12: P. 0890.

24. HA Batista, FN Silva, HM Lisboa, A Cristina, FM Costa, et al. (2020) Modeling and optimization of combustion synthesis for hydroxyapatite production. Ceramics International 46(8B): 11638-11646.

25.J Sang, S Rhee (2013) Formation mechanism of nano-sized hydroxyapatite powders through spray pyrolysis of a calcium phosphate solution containing polyethylene glycol. Journal of European Ceramic society. 33: 233-241.

26. T Taewana, R Wongmaneerung (2017) Synthesis Hydroxyapatite from Three Types Eggsshells by Co-Precipitation Method. Appl Mech Mater 866: 73-76.

27. FM Berruti, L Ferrante, CL Briens, F Berruti (2012) Pyrolysis of cohesive meat and bone meal in a bubbling fluidized bed with an intermittent solid slug feeder. Journal of Analytical and Applied Pyrolysis 94: 153162 .
28. E Cascarosa, I Fonts, JM Mesa, JL Sánchez, J Arauzo, et al. (2011) Characterization of the liquid and solid products obtained from the oxidative pyrolysis of meat and bone meal in a pilot-scale fluidised bed plant. Fuel Processing Technolology 92(11): 1954-1962.

29. JP Polin, CA Peterson, LE Whitmer, RG Smith, RC Brown, et al. (2019) Process intensification of biomass fast pyrolysis through autothermal operation of a fluidized bed reactor. Applied Energy 249: 276-285.

30. RC Brown (2003) Biorenewable Resources: Engineering New Products from Agriculture. Wiley.

31. JK Lindstrom, J Proano-Aviles, PA Johnston, CA Peterson, IS Stansell, et al. (2018) Competing reactions limit levoglucosan yield during fast pyrolysis of cellulose. Green Chemistry.

32. CJ Ellens, RC Brown (2012) Optimization of a free-fall reactor for the production of fast pyrolysis bio-oi. Bioresour Technol 103(1): 374-380.

33. I Milosavljevic, V Oja, EM Suuberg (1996) Thermal Effects in Cellulose Pyrolysis: Relationship to Char Formation Processes. I \& EC Research 35: 653-662.

34. PR Patwardhan (2010) Understanding the product distribution from biomass fast pyrolysis. Chem Eng 162.

35. J Fermoso, JM Coronado, DP Serrano, P Pizarro (2017) 11 - Pyrolysis of microalgae for fuel production. in: C Gonzalez, et al. (Eds.). Woodhead Publ Ser Energy. Woodhead Publishing pp. 259-281.

36. D Barik (2019) Energy extraction from toxic waste originating from food processing industries. Energy from Toxic Organic Waste for Heat and Power Generation 17-42.

37. AD Paulsen, MS Mettler, PJ Dauenhauer (2013) The role of sample dimension and temperature in cellulose pyrolysis. Energy and Fuels 27: 2126-2134.

38. T Funazukuri, RR Hudgins, PL Silveston (1986) Product distribution in pyrolysis of cellulose in a microfluidized bed. Journal of Analytical and Applied Pyrolysis 9: 139-158.

39. DA Laird, RC Brown, JE Amonette, J Lehmann (2009) Review of the pyrolysis platform for coproducing bio-oil and biochar, Biofuels. Bioprod Biorefining 3: 547-562.

40. BG Campo, RC Brown, DA Laird, M Mba-wright, MD Morris, et al. (2015) Production of activated carbon from fast pyrolysis biochar and the detoxification of pyrolytic sugars for ethanol fermentation. By Major Mechanical Engineer Program of Study Committee.

41. C Di Blasi (1996) Influences of model assumptions on the predictions of cellulose pyrolysis in the heat transfer controlled regime. Fuel 75: 58-66.

42. M Ayllón, M Aznar, JL Sánchez, G Gea, J Arauzo, et al. (2006) Influence of temperature and heating rate on the fixed bed pyrolysis of meat and bone meal. Chemical Engineering 121: 85-96.

43. E Cascarosa, A Boldrin, T Astrup (2013) Pyrolysis and gasification of meat-and-bone-meal: Energy balance and GHG accounting. Waste Manag 33: 2501-2508.

44. SA Opatokun, V Strezov, T Kan (2015) Product based evaluation of pyrolysis of food waste and its digestate. Energy 92: 349-354.

45. J Molto, MF Go, JA Conesa, R Font, A Fullana, et al. (2009) Comparison between emissions from the pyrolysis and combustion of different wastes. Journal of Analytical and Applied Pyrolysis 84: 95-102.

46. JS Cho, YC Kang (2008) Nano-sized hydroxyapatite powders prepared by flame spray pyrolysis. Journal of Alloys and Compounds 464(1-2): 282-287.

47. K Itatani, T Tsugawa, T Umeda, Y Musha, IJ Davies, et al. (2010) Preparation of submicrometer-sized porous spherical hydroxyapatite agglomerates by ultrasonic spray pyrolysis technique. J Ceram Soc Japan 118: 462-466. 
48. JS Cho, SH Rhee (2012) The densification mechanism of hydroxyapatite particles during spray pyrolysis with variable carrier gas rates of flow. Journal of Biomedical Materials research. Part B, Applied Biomaterials 100(2): 493-500.

49. G Gea, J Arauzo, E Cascarosa, MCO De Zarate (2012) Sulphur removal using char and ash from meat and bone meal pyrolysis. Biomass and Bioenergy 40: 190-193.

50. N Wakiya, M Yamasaki, T Adachi, A Inukai, N Sakamoto, et al. (2010) Preparation of hydroxyapatite-ferrite composite particles by ultrasonic spray pyrolysis. Materials Science and Engineering: B 173(1-3): 195198.

51. M Vallet-Regí, MT Gutiérrez-Ríos, MP Alonso, MI de Frutos, S Nicolopoulos, et al. (1994) Hydroxyapatite particles synthesized by pyrolysis of an aerosol. Journal of Solid State Chemistry 112(1): 58-64.

52. JS Cho, SH Rhee (2013) The size control of hydroxyapatite particles during spray pyrolysis. Key Engineering Materials. (529-530 ): 66-69.

53. J Sang, J Lee, S Hye, J Kon, S Rhee, et al. (2014) Effect of grain size and density of spray-pyrolyzed hydroxyapatite particles on the sinterability of hydroxyapatite disk Ceramics International 40(5): 6691-6697.

54.M Aguilar-Frutis, S Kumar, C Falcony (2009) Spray-pyrolyzed hydroxyapatite thin-film coatings Surface and Coatings Technology 204(6-7): 1116-1120.

55. B Purevsuren, B Avid, J Narangerel, T Gerelmaa, Y Davaajav, et al. (2004) Investigation on the pyrolysis products from animal bone. Journal of Materials Science 39: 737-740.

56. E Cascarosa, I Fonts, JM Mesa, JL Sánchez, J Arauzo, et al. (2011) Characterization of the liquid and solid products obtained from the oxidative pyrolysis of meat and bone meal in a pilot-scale fluidised bed plant. Fuel Processing Technology 92: 1954-1962.
57. F Lónyi, J Valyon, E Someus, J Hancsók (2013) Steam reforming of bio-oil from pyrolysis of MBM over particulate and monolith supported $\mathrm{Ni} / \mathrm{\gamma}$ Al203 catalysts. Fuel 112: 23-30.

58. JO Chae, SP Knak, AN Knak, HJ Koo, V Ravi, et al. (2006) Oyster shell recycling and bone waste treatment using plasma pyrolysis. Plasma Science and Technology 8: 712-715.

59. D Mohan, CU Pittman, PH Steele (2006) Pyrolysis of Wood/Biomass for Bio-oil: A Critical Review. Energy \& Fuels 20: 848-889.

60. D Ferdous, AK Dalai, SK Bej, RW Thring (2002) Pyrolysis of lignins: Experimental and kinetics studies. Energy and Fuels 16: 1405-1412.

61. S Papari, K Hawboldt (2015) A review on the pyrolysis of woody biomass to bio-oil: Focus on kinetic models. Renewable Sustain Energy Reviews 52: 1580-1595.

62. YS Choi, PA Johnston, RC Brown, BH Shanks, KH Lee, et al. (2014) Detailed characterization of red oak-derived pyrolysis oil: Integrated use of GC, HPLC, IC, GPC and Karl-Fischer. Journal of Analytical and Applied Pyrolysis 110: 147-154.

63. CM Lakshmanan, HE Hoelscher (1970) Production of Levoglucosan by Pyrolysis of Carbohydrates. Pyrolysis in Hot Inert Gas Stream. Ind Eng Chem Prod Res Dev 9: 57-59.

64. N Glæsner, H Christian, B Hansen, Y Hu, G Bekiaris, et al. (2019) Chemosphere Low crystalline apatite in bone char produced at low temperature ameliorates phosphorus-de fi cient soils. Chemosphere 223: 723-730.

65. JS Robinson, K Baumann, Y Hu, P Hagemann, L Kebelmann, P Leinweber (2018) Phosphorus transformations in plant-based and bio-waste materials induced by pyrolysis. Ambio 47(Suppl 1): 73-82. 